日泌尿会誌, 84 巻， 6 号，1993年：1082 1087

腎尿細管細胞（LLC-PK 1 ）に和ける蓚酸の能動的取り込み

国立南和歌山病院泌尿器科, *和歌山県立医科大学泌尿器科, **Department of Physiology and

***Division of Urology and Transplantation surgery, University of Massachusetts Medical School, Worcester, MA, USA

戎野 庄一 大川 順正* Cheryl Scheid**
Mani Menon***

\title{
ACTIVE UPTAKE OF OXALATE IN A RENAL TUBULAR CELL LINE (LLC-PK ) $^{2}$
}

\author{
Shoichi Ebisuno, Tadashi Ohkawa*, Cheryl Scheid** and Mani Menon*** \\ Department of Urology, Minami Wakayama National Hospital and *Wakayama Medical College \\ **Department of Physiology and ***Division of Urology and Transplantation Surgery, \\ University of Massachusetts Medical School, Worcester, MA, USA
}

The oxalate uptake was studied in LLC-PK ${ }_{1}$ cells, an epithelial cell line originated in proximal tubular cells of porcine kidney. It was clear that the cells contain an oxalate exchanger highly sensitive to 4,4-diisothio-cyanostilbene-2-' disulfonic acid (DIDS). The uptake was inhibited by the addition of inorganic anions (chloride, sulphate and bicarbonate) to the reaction system, but was unaffected by sodium ion. The data suggest the possibility that it should be consistent with at least two transport systems for oxalate in LLC-PK 1 cells, a $\mathrm{SO}_{4}{ }^{-}$/oxalate $/ \mathrm{HCO}_{3}{ }^{-}$exchanger and a $\mathrm{Cl}^{-}$/oxalate exchanger.

Key words: oxalate, LLC-PK 1 cell, anion transporter

\begin{abstract}
要旨：豚の近位尿細管由来の LLC-PK ${ }_{1}$ 細胞において $\left[{ }^{14} \mathrm{C}\right]$ にラベルされた蓚酸を用いて，細胞内への苳 酸の取り込みを検討した。

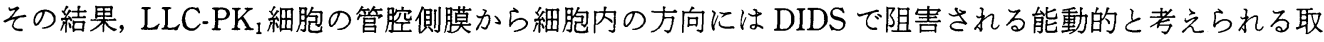
り込みが存在すること, 他の陰イオン（塩素, 重炭酸および硫酸）により阻害を受けること, 拈よびこ の輸送系はナトリウムイオン濃度には影響を受けないことなどを明らかにした。このような実験結果か

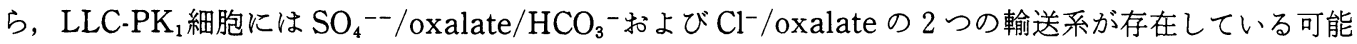
性が示唆された。
\end{abstract} キーワード：蓚酸，LLC-PK 1 細胞，陰イオン輸送

\section{緒言}

蓚酸は尿路結石の構成成分として極めて重要な物質 である、腎における苳酸の輸送形態の概略については 先人達の微細な free flow micropuncture plearance study により，ラットでは糸球体をほぼ自由に濾 過され，近位尿細管で分泌あるいは再吸収されること が示されて来ている $(1-4)$ ，また，細胞単位では， 近年, 腎皮質尿細管の細胞膜成分での苳酸の輸送形態 が受動払散と能動輸送系で構成されているであろらと する報告がみられて来ている(5-7).しかしながら， 微細な苳酸輸送に関しては，いままでは細胞膜成分で の検討にすぎず腎尿細管の細胞単位での検討はなされ ていなかった。
著者らは豚の近位尿細管細胞である LLC-PK ${ }_{1}$ 細胞 を用いて，蓚酸の微細輸送系，とくに刷子縁（brush border）側から細胞内への能動輸送について検討する と共に，塩素，硫酸，重炭酸イオンおよびナトリウム イオンの影響などを詳細に検討した。

\section{材料と方法}

細胞培養; LLC-PK 1 細胞は American Type Culture Collection（CRL 1392）の195代目を入手し，実 際の輸送系の実験には継代206代目から225代目が使わ れた。細胞の継代は10\%牛胎児血清 (Hyclone, Lab. Inc. Logan, Utah, USA)を混じた Dulbecco's modified Eagle's minimal essential medium (DMEM, GIBCO, Grand Island, New York, USA) 
にペニシリン $(100 \mathrm{U} / \mathrm{ml})$, ストレプトマイシン $(100$ $\mu \mathrm{g} / \mathrm{ml})$ および D-グルコース $(4,500 \mathrm{mg} / l)$ を加えた ものを細胞培養液として用い, 炭酸ガス培養器（ $5 \%$ $\mathrm{CO}_{2}, 95 \%$ air, $\left.37^{\circ} \mathrm{C}\right)$ で通常の方法で行った。また, 蓚酸の細胞内への取り込みの定量実験には，6穴の培 養用プレート $(25 \mathrm{~mm} /$ well, Nunc $) に 5 \times 10^{4} \mathrm{cell} / \mathrm{ml}$ の 細胞数に調整したものを, 各 well に $2 \mathrm{ml}$ づつ分注し, 3日目に confluence に到達したものを供した。

細胞内取り迈み実験； 3 日目に confluence に達し た細胞は, overgrowth や培養液内の種々の薬物の影 響などを取り除くために，取り込み実験開始日の 3 時 間前に完全培養液を牛胎児血清の添加していない $\mathrm{pH}$ 7.4の DMEM 培養液に替えることによって条件の一 定化を図った。細胞は Hank's balanced salt solution (HBSS) で洗浄された後, 常に 2 つの実験群に分けた. すなわち，一群はDMSO (dimethyl sulphoxide) で溶 解した $1 \mathrm{mM}$ 濃度の細胞膜における陰イオン輸送阻害 剤である4,4'-diisothio-cyanostilbene-2-2'disulfonic acid(DIDS)をHBSS に加えて, 各 well, $2 \mathrm{ml}$ づつ投 与し30分の前処理をしたものであり，この群で得られ た苳酸の細胞内取り込みは受動的拡散のみであろらと 考えた。

他の群はDIDSを添加せず，同濃度の DMSO のみ を加えた HBSS で同様の前処理を行うもので, この群 は受動的拡散と同時に能動的取り込みの両者をとらえ たものと考えた.

その後, $\left[{ }^{14} \mathrm{C}\right]$ にラベルされた蓚酸（最終濃度 100 $\mu \mathrm{M}$, New England Nuclear, Boston, Massachusetts,
USA）を加光，それぞれ1mMの DIDS（十）および $\operatorname{DIDS}(-)$ のBSS を基本の反応液とし, 種々の反応 時間および種々の反応液を作成し, 細胞内への取り込 みを室温で検討した。 基本の反応液(HBSS)の組成は, 以下のようである ; $\mathrm{NaCl}(138 \mathrm{mM}), \mathrm{KCl}(5.8 \mathrm{mM})$, $\mathrm{Na}_{2} \mathrm{HPO}_{4} / \mathrm{NaH}_{2} \mathrm{PO}_{4}(0.78 \mathrm{mM}), \mathrm{CaCl}_{2}(0.25 \mathrm{mM})$, $\mathrm{MgCl}_{2}(0.25 \mathrm{mM})$, HEPES (N-2-hydroxyethyl piperazine- $\mathrm{N}^{\prime}$-2-ethanesulfonic acid, $\left.10 \mathrm{mM}\right), \mathrm{pH}$ 7.4. 硫酸イオンの影響を検討する際には $\mathrm{KCl}$ を $\mathrm{K}_{2}$ $\mathrm{SO}_{4}$ に替え, 塩素イオンの影響の検討では $\mathrm{KCl}, \mathrm{MgCl}_{2}$ おょび $\mathrm{NaCl}$ 各々gluconate $\mathrm{K}, \mathrm{MgSO}_{4}$ および gluconate $\mathrm{Na}$ に替えて苳酸の細胞内取り込み実験を 行った。また，重炭酸イオンの検討には $\mathrm{NaCl}$ を $\mathrm{NaHCO}_{3}$ に替え,ナトリウムイオンの影響をみる際に は $\mathrm{NaCl}$ を choline chlorideに置き換え検討した。

種々に設定された条件での反応を行った後，その反 応液を除去し, その後, 苳酸ナトリウム $(100 \mu \mathrm{M})$ を 混じた冷い生理食塩水 $(10 \mathrm{ml})$ で 2 回洗浄した。さら に細胞を10\%トリクロロ酢酸（2ml）で処理した後, scraperを用いすべての細胞を剥離し，シンチレー ションバイヤルに移して, radioactivityを測定した。 毎回の実験に使用された生細胞数は trypan blue dye exclusion 法を用いた hemocytometer で算定し，細胞 内への蓚酸の取り込みを p moles $/ 10^{6}$ cell で表わし た.

なお，実験方法の概略はFig. 1 に示した。

また，HBSS という基本の反応液を使用した場合の 細胞の蓚酸の取り込みについての時間および濃度依存

\section{図 1 実験方法概略}
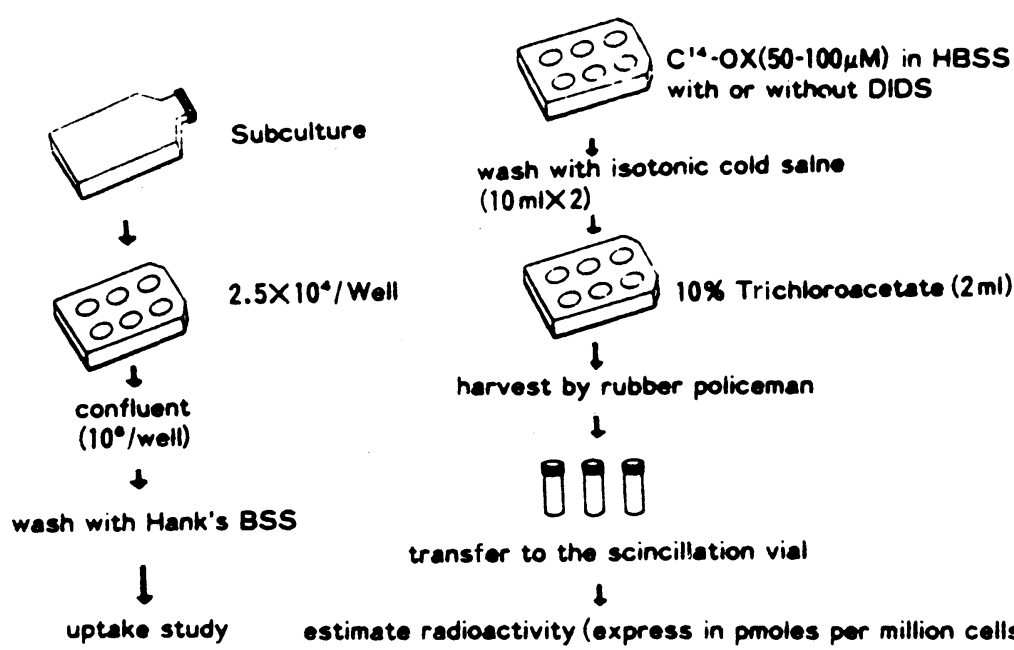

transfer to the scincillation vial

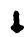

uptake study estimate radioactivity (express in pmoles per million cells) 


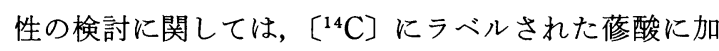
光, [methyl $\left.{ }^{3} \mathrm{H}\right]$ inulin を用いて細胞間吵やその他へ の苳酸の非特異的な取り込みを各濃度および各時間に ついて各 3 回検討した結果, 平均 $17 \%$ の細胞膜内以外 の部位に蓚酸が trapping されていることがわかり, 上 記の時間拈よび濃度に関する結果は得られたデータに 0.83を乗じたものとした。しかし，種々の個別の条件 での double isotope methodによる, 個々の蓚酸の trapping 率は検討されなかった。

統計的な有意差検定はコンピュータ一解析 (Statview, Brainpower Inc, Calabasas, California) で扣こない, ANOVA (multiple comparisons with a single cotrol) および Scheffe's test (all posible comparisons）を利用し分析され， $\mathrm{p}<0.05 て ゙$ 有意なものと 判定した.

\section{結 果}

陰イオン能動的輸送の抑制物質である DIDS の細胞 内蓚酸取り込みに対する効果; 図 2 に示したよらに DIDS で30分間前処理すると $0.5 \mathrm{mM}$ から有意に細胞 内への蓚酸の取り込みが抑制されたが， $1 \mathrm{mM}$ 以上の 濃度での抑制効果の増強はみられなかった。この結果 から，その後の DIDSを用いての前処理は $1 \mathrm{mM}$ とし た.

細胞内一の蓚酸取り込みの時間依存性；DIDS で処 理しなかったものに拈ける細胞内への取り込み（total uptake）を受動的拡散および能動的取り込みの両者々 考光，DIDSで前処理したものに打ける取り込み (DIDS insensitive uptake) を受動的拡散のみと考克 ると，その取り込みの差（DIDS sensitive uptake）が 能動的取り込みを現わすものであろうと考えられた。

図 2 DIDSによる蓚酸の細胞内取り込み抑制率。 データは mean $\pm \operatorname{SE}(n=6)$ で示し, DIDS の無添加 に比較した時, ${ }^{*} \mathrm{p}<0.05,{ }^{*} \mathrm{p}<0.01$ と統計的有意差 が示された。

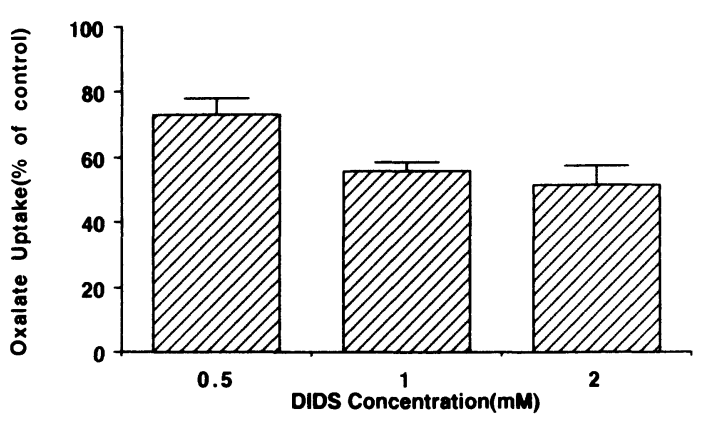

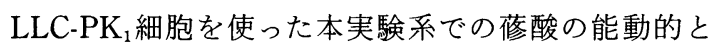
考えられる取り込みは，Fig. 3 に示したように 2 時間 までは時間依存性が認められるが，その後は平衡状態 であった。

濃度依存性; 蓚酸濃度を $50 \mu \mathrm{M}$ から $1 \mathrm{mM}$ まで変化 させて細胞内への蓚酸の取り込みを測定したが, DIDS sensitive uptake は200 $\mu \mathrm{M}$ でほぼ平衡に達し（Fig. 4a), Hanes-Woolf plot から本実験系での蓚酸の細胞 内への DIDS sensitive uptake の $\mathrm{K}_{\mathrm{m}}$ は $45 \mu \mathrm{M}$ と計算

因 3 細胞内への蓚酸取り込みの時間依存性。本文中 に示したようにDIDS sensitive uptakeは Total uptakeより DIDS insensitive uptakeを差し引い たものとした。なお，データは mean $\pm \mathrm{SE}(\mathrm{n}=9)$ で示した。

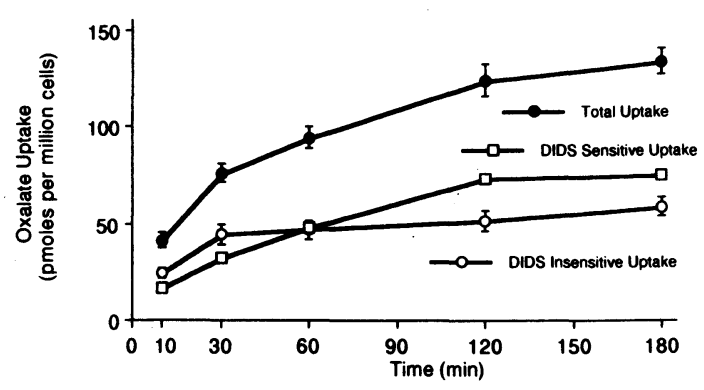

図 $4 \mathrm{a}$ : 細胞内への蓚酸の濃度依存性取り込み。 データは mean $\pm \mathrm{SE}(\mathrm{n}=6)$ で示した. $\mathrm{b}$ : HanesWoolf plot ([S/v]vs[S])における DIDS sensitive uptakeの $\mathrm{K}_{\mathrm{m}}$ は $45 \mu \mathrm{M}$ であった。
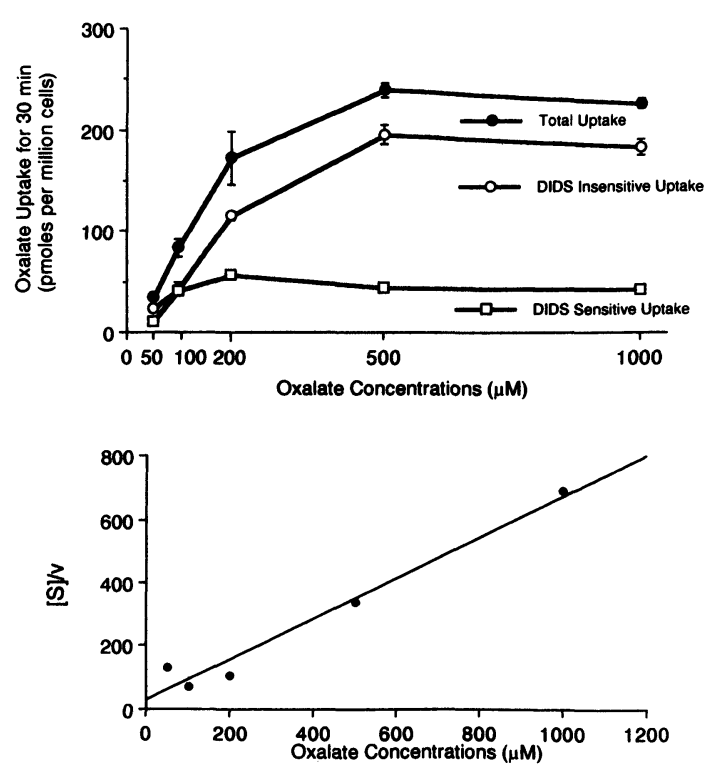
図 5 細胞内への蓚酸取り込みに対する硫酸イオンの 影響. データは mean $\pm \mathrm{SE}(\mathrm{n}=6)$ で示した $\left({ }^{* *} \mathrm{p}<\right.$ 0.01 ).

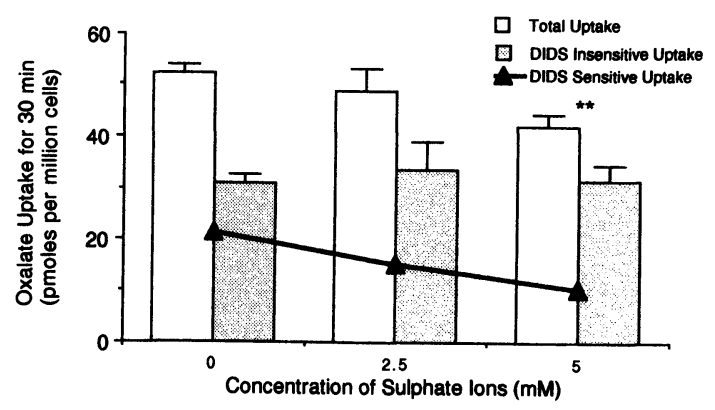

図 6 細胞内への蓚酸取り込みに対する重炭酸イオン の影響. 細胞内取り込みは10分間の反応のものであ ク, データは mean $\mathrm{SE}(\mathrm{n}=6)$ で示した（*p< $\left.0.05,{ }^{* *} \mathrm{p}<0.01,{ }^{* * *} \mathrm{p}<0.001\right)$.

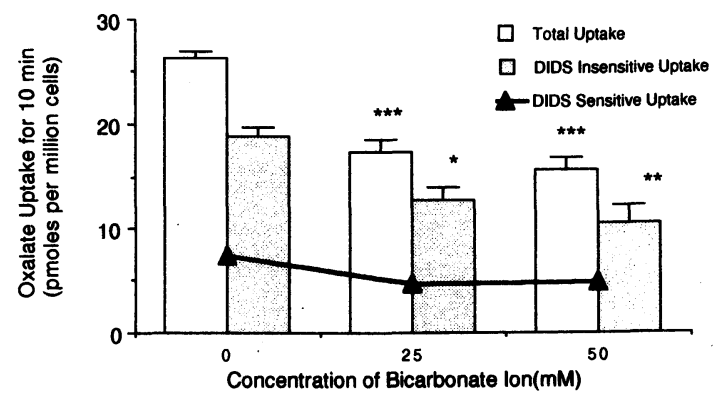

できた（Fig. 4b).

硫酸イオンの影響; Fig. 5 に示したように細胞外 液の硫酸イオンを変化させると, DIDS 無処理群での 取り込み（total uptake）は有意に下がるが, DIDS 前 処理群は変化せず, 両者の差, すなわち, DIDS sensitive uptake は硫酸イオンが存在すると有意に減少し た。この結果から，蓚酸と硫酸はDIDSに影響を受け る陰イオンの輸送システムを共有しあっている可能性 が示唆された。

重炭酸イオンの影響；25mM および50mM の塩化 ナトリウムを重炭酸ナトリウムに置換して検討した が，反応液の重炭酸イオン濃度が安定なのは 10 分間以 内との初期実験結果を得ているため, 図 6 の結果は他 と違って10分間での細胞内への取り込みを示したもの である.重炭酸イオンを添加すると蓚酸の DIDS sensitive uptake が明らかに減少し, 蓚酸と重炭酸イオンは 共通の輸送システムをもつ可能性が考えられた。

塩素イオンの影響 ; 反応液中の $\mathrm{KCl}$ および $\mathrm{MgCl}_{2}$
図 7 細胞内への蓚酸取り込みに対する塩素イオンの 影響. データは mean $\pm \mathrm{SE}(\mathrm{n}=6)$ で示した $\left({ }^{* *} \mathrm{p}<\right.$ $\left.0.01,{ }^{* * *} \mathrm{p}<0.001\right)$.

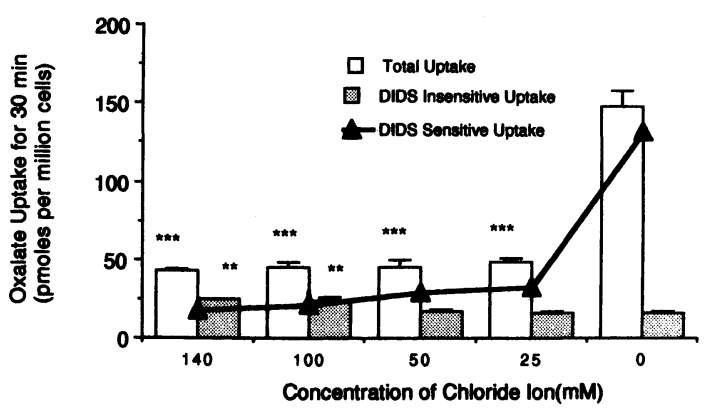

図 8 細胞内への蓚酸取り込みに対するナトリウムイ オンの影響. データは mean $\pm \mathrm{SE}(n=6)$ で示した。

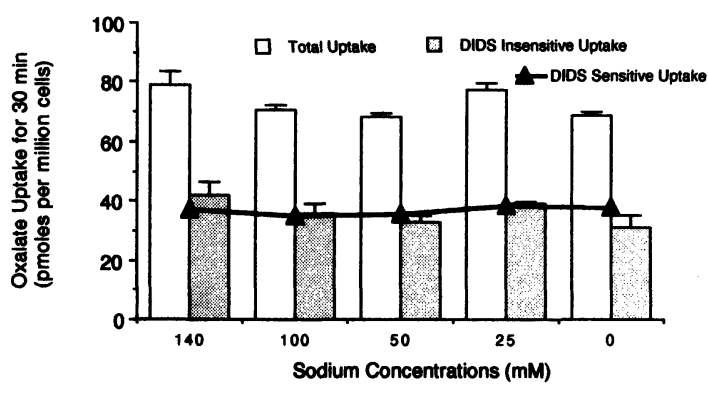

を各々gluconate $\mathrm{K}$ おび $\mathrm{MgSO}_{4}$ に置換し， $\mathrm{NaCl}$ に 対応する量を gluconate $\mathrm{Na}$ に替えて蓚酸の細胞内取 り込みを検討したが，塩素イオンが減少するにつれ苳 酸の DIDS sensitive uptake が徐々に増加し, 塩酸イ オンの欠落状態では極めて著明な取り込みを示した (因 7 ).この結果から，LLC-PK 1 細胞においては蓚酸 と塩素は競合し，共通の輸送系を有している可能性が 示唆された。

ナトリウムオイオンの影響; $\mathrm{NaCl} の$ 対応量を choline chloride に置換してナトリウムイオンの影響 をみた。四8に示したごとくナトリウムイオンには葆 酸の total uptake および DIDS insensitive uptake に 全く有意の影響を与えず，本実験系ではDIDS sensitive uptakeは陽イオンであるナトリウムには影響を 受け得なかった。

\section{考察}

現在までラットにおける free flow micropuncture や clearance studyにおいて葆酸は糸球体をほぼ自由 に濾過され(1)，近位尿細管で分泌あるいは再吸収さ れることが示されて来ている $(1-4)$ ，これに関連す 
図 9 いままでに明らかにされているラット腎での蓚酸の分泌および再吸収の模式

図.

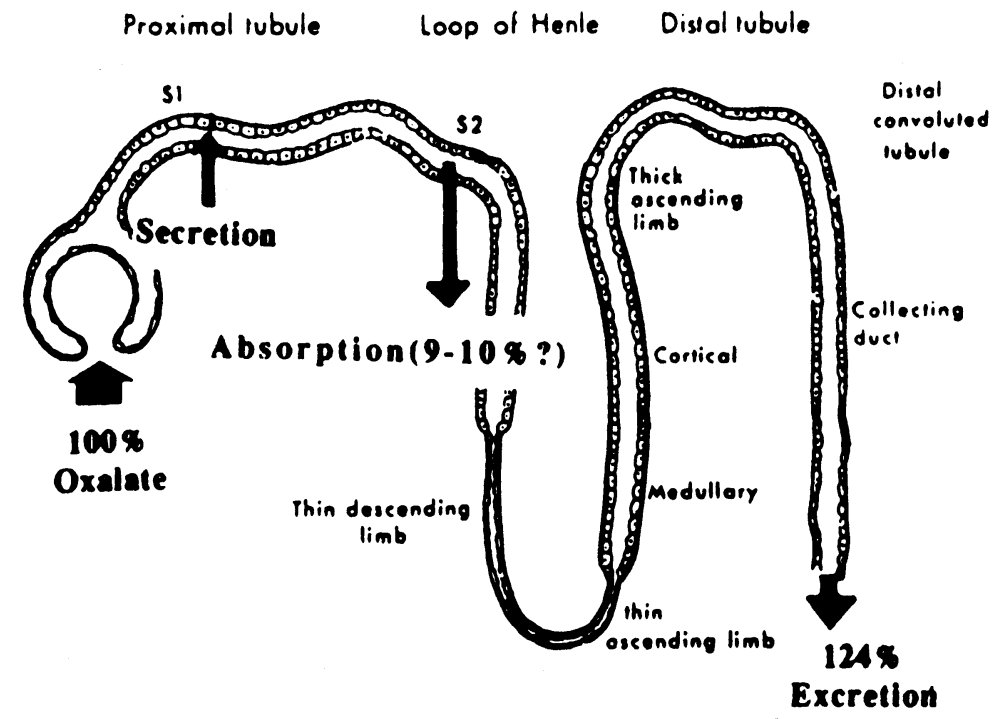

図10 腎尿細管細胞膜での $\mathrm{Cl}^{-}$/oxalate イオンの相 互交換の模式図 (Aronson（8）の総説から引用).

LUMEN

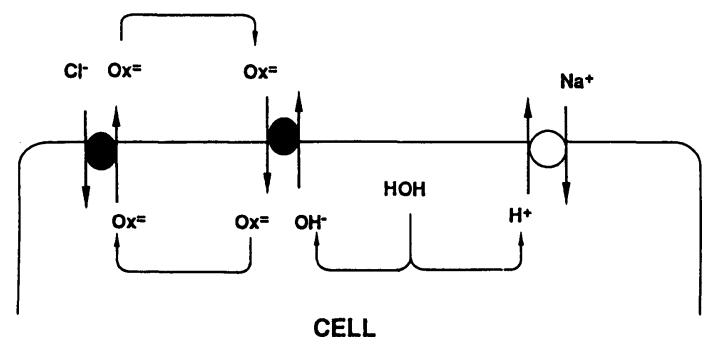

る文献を引用して記載すると，ラットの腎での蓚酸の 分泌・再吸収は図 9 に示す通りである。

$\mathrm{LLC} \mathrm{PK}_{1}$ 細胞の塩素イオンと蓚酸の取り込みの競 合阻害は明らかであり, 細胞膜上での苳酸イオンと塩 素イオンとの交換の模式図を, 今回の結果と Aronson (8) および Yamakawa \& Kawamura（6）の論文 を参照にすると図10に示したようなものが想定でき る.

また，苳酸が重炭酸および硫酸イオンと同一の陰イ オン交換系をもっていることは家鬼 $(7,8)$, ラット （9，10）あるいは仔牛（11）の尿細管の膜成分を用い め既に個別にさまざまの方法でその確認がなされてい る.

他方，ナトリウムイオンと蓚酸輸送の関連性につい ては,ナトリウム依存性があるとする報告 $(6,7)$,
および著者らの結果と同様に全く影響のない輸送系で ある（8）とする説の両者があり，この点も今後の検 討が待たれるところであるが，著者らの実験では蓚酸 が直接的に関与する陰イオンの輸送系はナトリウムと の関連性がないと思われる結果が得られた。

今回の実験に使用された LLC-PK 1 細胞は, 近位尿 細管として多くの性質をもっており，既に各種イオン やアミノ酸を初めとする種々の物質の輸送系の研究 (12-16)などに用いられており，陰イオンの 1 つであ る苳酸の尿細管レベルでの輸送形態の研究には適する ものと思われる。しかしながら，放射線性物質にラべ ルされた物質を用いての輸送形態の実験には，非特異 的に trapping される部分が存在するといら事実, さら に常に細胞の viabilityを一定にするにはかなりの困 難があることなどの多くの問題点があることも事実で ある.

苳酸の腎でのハンドリングの検討は，従来より腎皮 質から分離された膜成分を用いて行われて来ていると ころであるが, 本研究のように monolayer に発育し尿 細管を想定できる LLC-PK 1 細胞を用いることによ り，管腔側膜（brush border membrane）あるいは間 質側膜（basolateral membrane）からの能動的な蓚酸 転送・輸送の検討が可能になり，さらに，腎結石など の尿細管での苳酸輸送系の異常が関連しているであろ ら疾患では，その核心に迫る可能性をらかがえるもの と思われる。 
結 語

豚の近位尿細管由来の LLC-PK 1 細胞において $\left[{ }^{14} \mathrm{C}\right]$ にラベルされた蓚酸を用いて，細胞内への蓚酸の取り 込みを検討した。 その結果, LLC-PK ${ }_{1}$ 細胞の管腔側膜 から細胞内の方向には DIDS で阻害される能動的と考 えられる取り込みが存在すること, 他の陰イオン（塩 素，重炭酸および硫酸）により阻害を受けること，お よびこの輸送系はナトリウムイオン濃度には影響を受 けないことなどを明らかにした。このよらな実験結果 から，LLC-PK 1 細胞には $\mathrm{SO}_{4}{ }^{--}$/oxalate $/ \mathrm{HCO}_{3}{ }^{-}$抽よ び $\mathrm{Cl}^{-}$/oxalate の 2 つの輸送系が存在している可能性 が示唆された。

\section{文 献}

1) Weinman, E.J., Frankfult, S.J., Ince, A. and Sansom, S.C.: Renal tubular transport of organic acids. Studies with oxalate and paraaminohippurate in the rat. J. Clin. Invest., 61 , 801-806, 1978.

2) Greger, R., Lang, F., Oberleithner, H. and Deetjen, P.: Handling of oxalate by the rat kidney. Pflugers Arch., 374, 243-248, 1978.

3) Knight, 'T.F., Sansom, S.C., Senekjian, O.H. and Weinman, E.J.: Oxalate secretion in the rat proximal tubule. Amer. J. Physiol., 240, F295 -F298, 1981.

4) Senekjian, O.H. and Weinman, E.J.: Oxalate transport by proximal tubule of the rabbit kidney. Amer. J. Physiol., 243, F271-F275, 1982.

5) Karniski, L.P. and Aronson, P.S.: Anion exchange pathways for C1-transport in rabbit renal microvillus membranes. Am. J. Physiol., 253, F513-F521, 1987.

6) Yamakawa, K. and Kawamura, J.: Oxalate: $\mathrm{OH}$ exchange across rat renal cortical brush border. Kidney Int., 37, 1105-1112, 1990.

7) Kuo, S.M. and Aronson, P.S.: Oxalate transport via the sulfate $/ \mathrm{HCO}_{3}$ exchanger in rabbit renal basolateral membrane vesicles. J. Biol. Chem., 263, 9710-9717, 1988.

8) Aronson, P.S.; The renal proximal tubule: A model for diversity of anion exchangers and stilbene-sensitive anion transportes. Ann. Rev. Physiol., 51, 419-441, 1989.

9) Ullrich, K.J., Rumrich, G. and Kloss, S. : Contraluminal sulfate transport in the proximal tubule of the rat kidney. III. Specificity : Disulfonates, di- and tricarboxylates and sulfocarboxylates. Pflugers Arch., 404, 300-306, 1985.

10) Bastlein, C. and Burckhardt, G. ; Sensitivity of rat renal luminal and contraluminal sulphate transport systems to DIDS. Am. J. Physiol., 250, F226-F234, 1986.

11) Talor, Z., Gold, R.M., Yang, W.C. and Arruda, J.A.L. : Anion exchanger is present in both luminal and basolateral renal membranes. Eur. J. Biochexm., 164, 695-702, 1987.

12) Hull, R.M., Cherry, W.R. and Weaver, G.W.: The origin and characteristics of a pig kidney cell strain, LLC-PK ${ }_{1}$. In Vitro, 12, 670-677, 1976.

13) Rabito, C.A. and Ausiello, A.: $\mathrm{Na}^{+}$-dependent sugar transport in a cultured epithelial cell line from pig kidney. J. Membr. Biol., 54, 31-38, 1980.

14) Cantiello, H.F. and Rabito, C.A.: Effects of amiloride and $\mathrm{Ca}^{2+}$ on $\mathrm{Na}^{+} 22$ transport by LLC-PK ${ }_{1}$ monolayers. Kidney Int., 25, 296, 1984.

15) Rabito, C.A.: Phosphate uptake by a kidney cell line (LLC-PK ${ }_{1}$ ). Am. J. Physiol., 245, F22 $-\mathrm{F} 31,1983$.

16) Caverzasio, J., Brown, C.D.A., Biber, J., Bonjour, J.P. and Hurrer, H.: Adaptation of phosphate transport in phosphate-deprived LLC-PK cells. Am. J. Physiol., 248, F122-F127, 1985.

（1993年 1 月11日受理） 